\title{
Neurofibromatosis type-1 is a prognostic indicator in human gastric carcinoma
}

\author{
Debao Liu ${ }^{1,2, *}$, Yueying Zhang ${ }^{3, *}$, Yan Li $^{4}$ and Kaixi Fan ${ }^{1}$ \\ ${ }^{1}$ Department of Oncology, Affiliated Hospital of Shandong Academy of Medical Sciences, Jinan, Shandong, China \\ ${ }^{2}$ School of Medicine and Life Sciences, University of Jinan-Shandong Academy of Medical Sciences, Jinan, Shandong, China \\ ${ }^{3}$ Department of Pathology and Pathophysiology, Institute of Basic Medicine, Shandong Academy of Medical Sciences, Jinan, \\ Shandong, China \\ ${ }^{4}$ Department of Central Laboratory, Affiliated Hospital of Shandong Academy of Medical Sciences, Jinan, Shandong, China \\ "These authors have contributed equally to this work \\ Correspondence to: Kaixi Fan, email: fankaixiyx@sina.com \\ Keywords: gastric cancer, neurofibromatosis type I, TNM stage, immunohistochemistry, prognosis \\ Received: December 02, $2016 \quad$ Accepted: July 06, $2017 \quad$ Published: August 03, 2017 \\ Copyright: Liu et al. This is an open-access article distributed under the terms of the Creative Commons Attribution License 3.0 \\ (CC BY 3.0), which permits unrestricted use, distribution, and reproduction in any medium, provided the original author and source \\ are credited.
}

\section{ABSTRACT}

We investigated whether the Neurofibromatosis type-1(NF1) gene was of prognostic relevance to gastric cancer (GC) patients. Immunohistochemical staining of 160 matched GC tumor and adjacent normal tissue samples showed that $\mathbf{5 8 . 1 \%}$ $(93 / 160)$ of GC samples were NF1-positive as compared to $94.4 \%(151 / 160)$ of normal tissue samples $\left(X^{2}=58.05, P<0.001\right)$. qRT-PCR analysis revealed that NF1 mRNA expression is lower in GC tissues than normal tissues $\left(X^{2}=34.23, P<0.001\right)$. Moreover, NF1 protein and mRNA levels were associated with T stage $(P<0.05)$ and TNM $(P<0.001)$. No association was observed with other clinicopathological parameters, including gender, age, tumor size, lymph-node metastasis, cancer differentiation and distant metastasis (all $P>0.05$ ). Kaplan-Meier analysis revealed that negative or low NF1 were associated with poor overall survival (OS) in gastric cancer patients $(P<0.001)$. Further univariate and multivariate cox regression analysis also showed that NF1 expression was an independent risk factor of survival of GC patients. These data show that NF1 has prognostic relevance to clinical outcomes in gastric cancer patients.

\section{INTRODUCTION}

Gastric cancer (GC) is the third leading cause of cancer-related deaths and the fourth most common malignant tumors [1]. Most GC patients are diagnosed at an advanced stage with lymph nodes metastasis [2]. Most patients experience metastasis and recurrence after undergoing standard treatment that includes adjuvant chemoradiotherapy and surgery. Hence, the 5-year survival rate of GC is very poor $[3,4]$. Therefore, new prognostic tumor markers and therapeutic targets are necessary to improve the clinical outcomes for GC patients.
Neurofibromatosis type-1(NF1) or von Recklinghausen disease is a common autosomal dominant condition affecting the nervous system with an estimated incidence of about 1 in 3,000-4,000 individuals worldwide [5, 6]. It is also a multi-system disease associated with many cancers $[7,8]$. The NF1 gene is a classic tumor suppressor gene located on chromosome 17q11.2 and its product neurofibromin is an important negative regulator of Ras signaling pathway $[9,10]$. Mutations in NF1 gene result in NF1 disease. Many studies have demonstrated that $N F 1$ plays an important role in many cancers such as brain tumors [11], breast cancer [12], sporadic colon cancer [13], lung cancer [14], pheochromocytomas 
[15] and ovarian tumors [16]. Moreover, Vizcaino et al. demonstrated that glioma patients with low NF1 expression were associated with poor overall survival and diseasespecific survival [17]. In this study, we investigated the relationship between $N F 1$ expression and clinicopathological characteristics of GC patients. Further, we analyzed the prognostic relevance of NF1 for GC patients.

\section{RESULTS}

\section{NF1 protein expression in human gastric cancer tissues}

First, we analyzed NF1 protein expression in 160 GC and paired non-cancerous tissues. We observed that the NF1 protein was mainly located in the cytoplasm. Its expression was higher in the normal gastric tissues $(94.4 \%)$ compared to GC tissues (58.1\%) (Table $1 ; \chi 2=58.05, P$ $<0.001)$. Moreover, higher number of GC samples (59/93) demonstrated lower NF1 expression compared to normal gastric tissues $(25 / 151 ; \chi 2=56.04, P<0.001)$. However, we did not find any difference in NF1 expression among the superior differentiation (well-differentiated tumors), moderate differentiation (moderately differentiated tumors) and the inferior differentiation (poorly differentiated and mucinous adenocarcinoma) groups $\left(\chi^{2}=3.429\right.$, $P=0.489)$. Representative immunohistochemical images of NF1 protein expression in normal and cancer tissues are presented in Figure 1.

\section{Relation between NF1 protein expression and clinicopathological features}

We further divided the 160 cancer tissues into high, low and negative NF1 protein expression groups and assessed the correlation between NF1 expression and clinicopathological characteristics. Our data demonstrated that NF1 expression was associated with T stage $\left(\chi^{2}=15.36, P=0.018\right)$ and TNM stages $\left(\chi^{2}=27.39\right.$, $P<0.001$; Table 2). However, as shown in Table 2, NF1 was not associated with gender $(P=0.693)$, age $(P=0.971)$, tumor size $(P=0.959)$, lymph-node metastasis $(P=0.667)$, cancer differentiation $(P=0.489)$ and distant metastasis $(\mathrm{p}=0.966)$.

\section{Relationship between NF1 protein expression and the prognosis of these gastric cancer patients}

At the end of the five-year follow-up (median,45months), 48 out of 160 patients were alive. Among them, 36 patients that showed NF1 protein expression had better prognosis compared to 12 patients with negative NF1 protein expression $(\chi 2=8.023$, $P=0.005)$. In addition, among the 36 patients showing positive NF1 expression, 20 had high NF1 protein levels compared to 16 with low NF1 protein $(\chi 2=9.139$,
$P=0.003)$. The Kaplan-Meyer survival analysis results demonstrated that GC patients with high NF1 protein expression had a longer five-year overall survival than GC patients with low or negative NF1 protein expression $(\chi 2=20.732, P<0.001$; Figure 2A). Furthermore, the log-rank test demonstrated that GC patients with low or negative expression of NF1 protein had a poorer prognosis than those with high NF1 expression $(\chi 2=10.56, P=0.001)$.

\section{Expression level of NF1 mRNA in human gastric cancer tissues}

Next, we performed real time quantitative PCR (qRT-PCR) to compare NF1 mRNA levels in gastric cancer and matched adjacent normal tissues. NF1 mRNA could be detected in both or one of the cancerous and matched adjacent normal tissues, or alternatively, none of the cancerous and adjacent normal tissues. The interassay coefficient of variation was $<15 \%$ (in $\log$ scale) for this assay in our laboratory. Therefore, a 10-fold (one $\log$ ) difference was not caused by inter-assay variations and should be considered an authentic difference in NF1 expression levels. All cancer tissues were grouped into three groups: $N F 1_{\text {high }}, N F 1_{\text {low }}$ and $N F 1_{\text {negative }}$ expression group, the cancer tissues were designated as negative expression when NF1 mRNA was undetectable in cancer samples, the cancer tissues were designed as low expression when NF1 mRNA was detectable but the level was 10-fold lower than that in the adjacent normal tissues, and the cancer tissues were designed as high expression when NF1 mRNA was detectable and the level was either higher than, equal to, or lower (but less than 10 -fold difference) than that in the adjacent normal tissues.

The qRT-PCR results showed that $96.3 \%$ (154/160) normal and 72.5\% (116/160) gastric cancer tissues demonstrated NF1 mRNA expression (Table 3; Figure 3A). Our data showed that NF1 mRNA expression was significantly different between the gastric cancer and normal tissues $(\chi 2=34.23, P<0.001)$. However, NF1 mRNA expression was similar among different differentiation groups $\left(\chi^{2}=3.707\right.$, $P>0.05$; Figure $3 \mathrm{~B})$. These data further confirmed the immunohistochemical analysis, demonstrating that NF1 was highly expressed in normal tissues compared to gastric cancer tissues.

\section{Relation between NF1 mRNA expression and clinicopathological features}

When we compared NF1 mRNA expression with different clinicopathological features, we found no significant differences in relation to gender $(P=0.141)$, age $(P=0.800)$, tumor size $(P=0.980)$, lymph-node metastasis $(P=0.217)$, differentiation $(P=0.476)$ and distant metastasis $(P=0.416)$. 
Table 1: NF1 protein expression in normal and gastric cancer tissues based on immunohistochemistry

\begin{tabular}{lcccc}
\hline Tissue type & Total $(\mathbf{n})$ & NF1 positive & \% NF1 positives & $P$ value \\
\hline normal & 160 & 151 & 94.4 & $<0.001$ \\
cancer & 160 & 93 & 58.1 & \\
\hline
\end{tabular}

However, NF1 mRNA levels correlated with T stage $\left(\chi^{2}=16.04\right.$, $P=0.014)$ and TNM stages $\left(\chi^{2}=22.47, P<0.001\right.$; Table 4).

\section{Relationship between NF1 mRNA expression and the prognosis of these gastric cancer patients}

After a five-year follow-up, we found that patients with NF1 mRNA expression had better prognosis than those with negative NF1 mRNA expression $(\chi 2=9.475$, $P=0.002$ ). Furthermore, Kaplan-Meier analysis showed that patients with high NF1 mRNA expression had better overall survival than patients with low or negative NF1 mRNA expression $(\chi 2=19.599, P<0.001$; Figure $2 \mathrm{~B})$. These results showed that high NF1 mRNA expression indicated better prognosis for $\mathrm{GC}$ patients.

\section{NF1 expression was an independent variable closely related to patients' survival}

Further univariate and multivariate cox regression analysis showed that NF1 expression (HR, 1.57, 95\%CI: 1.216-2.025; $P=0.001)$ was an independent risk factor of survival of GC patients. Meanwhile, T stage (HR, 1.56, 95\%CI: $1.203-2.023 ; P=0.001$ ) was also found to be significantly associated with GC patients' survival (Table 5).

\section{DISCUSSION}

The NF1 gene is one of the largest genes in the human genome, located at chromosome 17q11.2 and having 60 exons spanning over $350 \mathrm{~kb}$ of genomic DNA [18, 19]. Recent studies have shown that NF1 is a tumor suppressor that plays a critical role in many cancers [20, 21]. Mutations in NF1 also lead to abnormalities in the cardiovascular, musculoskeletal and nervous systems [22]. Moreover, Iyengar et al. demonstrated that differential expression of the NF1 isoforms was associated with cellular differentiation in ovarian epithelial cancer [23]. To our knowledge, the relationship between NF1 and GC is unknown. Therefore, we systematically evaluated the expression of NF1 in normal and cancer GC tissues and investigated its prognostic relevance in GC.

In the present study, immunohistochemical staining and qRT-PCR analysis demonstrated that NF1 protein and mRNA levels were significantly reduced in GC cancer tissues compared to normal tissues. Immunohistological staining showed that $94.4 \%$ normal tissue samples positively stained
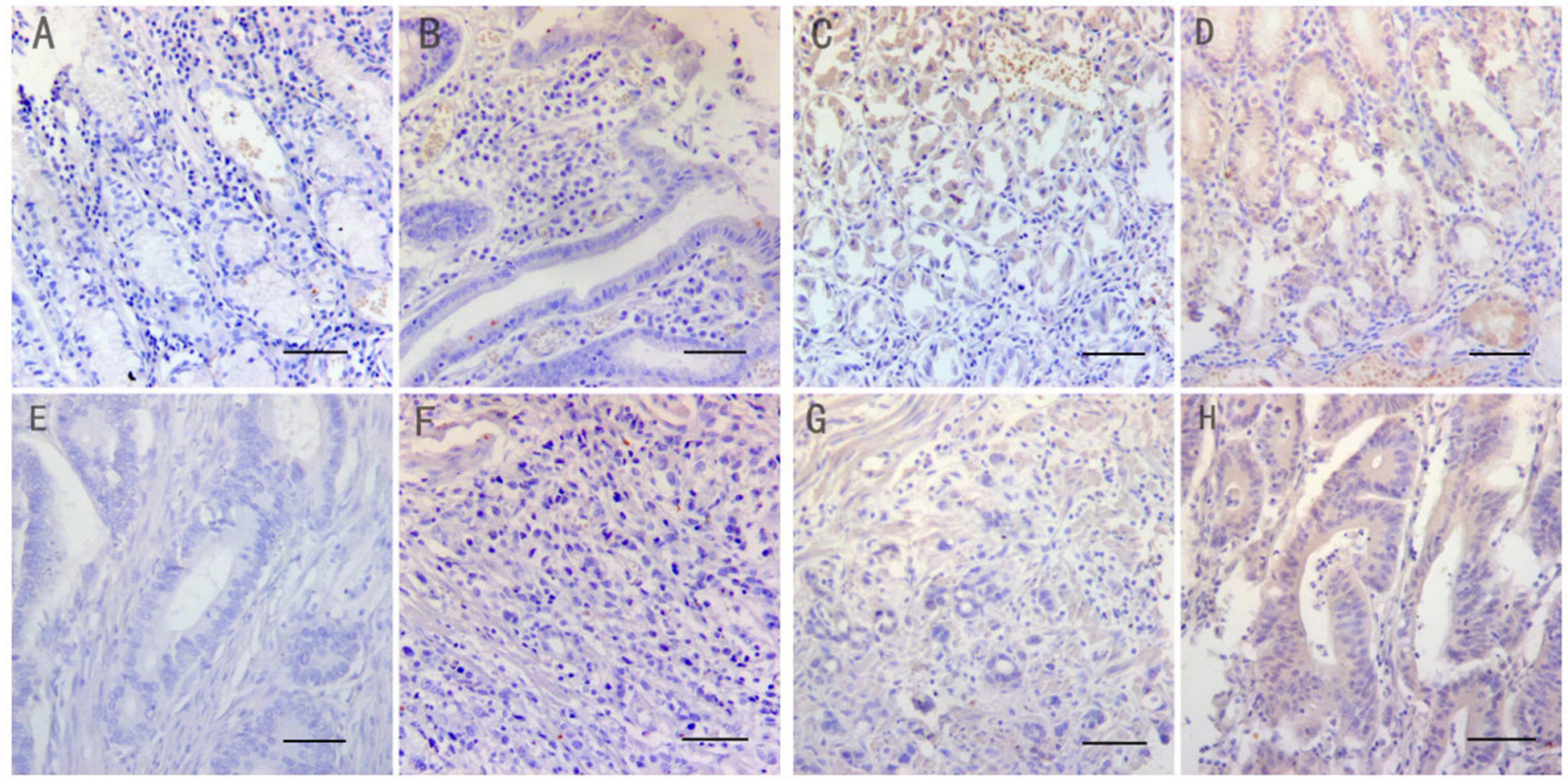

Figure 1: Immunohistochemical staining of NF1 in matched normal and gastric cancer tissues (Magnification: x200.

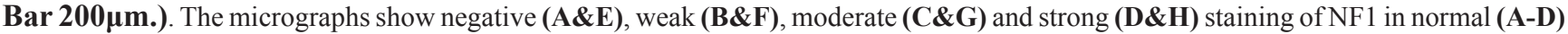
and cancer tissues $(\mathbf{E}-\mathbf{H})$, respectively. 
Table 2: Correlation between NF1 protein expression and clinicopathological characteristics of GC patients

\begin{tabular}{|c|c|c|c|c|c|}
\hline \multirow[t]{2}{*}{ Characteristics } & \multirow[t]{2}{*}{ n $(\%)$} & \multicolumn{3}{|c|}{ NF1 protein expression (case) } & \multirow[t]{2}{*}{ Pvalue } \\
\hline & & High $(n=34)$ & Low $(n=59)$ & Negative $(n=67)$ & \\
\hline \multicolumn{6}{|l|}{ Age (years) } \\
\hline$<60$ & $64(40)$ & 13 & 24 & 27 & 0.971 \\
\hline$\geq 60$ & $96(60)$ & 21 & 35 & 40 & \\
\hline \multicolumn{6}{|l|}{ Gender } \\
\hline Male & $104(65)$ & 23 & 40 & 41 & 0.693 \\
\hline Female & $56(35)$ & 11 & 19 & 26 & \\
\hline \multicolumn{6}{|l|}{ Tumor size (cm) } \\
\hline$<5$ & $91(57)$ & 19 & 33 & 39 & 0.959 \\
\hline$\geq 5$ & $69(43)$ & 15 & 26 & 28 & \\
\hline \multicolumn{6}{|l|}{ Distant metastasis } \\
\hline Yes & $16(10)$ & 3 & 6 & 7 & 0.966 \\
\hline No & 144(90) & 31 & 53 & 60 & \\
\hline \multicolumn{6}{|l|}{ T stage } \\
\hline $\mathrm{T} 1$ & $16(10)$ & 9 & 5 & 2 & 0.018 \\
\hline $\mathrm{T} 2$ & $21(13)$ & 5 & 7 & 9 & \\
\hline $\mathrm{T} 3$ & $92(58)$ & 16 & 36 & 40 & \\
\hline $\mathrm{T} 4$ & $31(19)$ & 4 & 11 & 16 & \\
\hline $\mathrm{N}$ stage & & & & & 0.667 \\
\hline N0 & $48(30)$ & 10 & 19 & 19 & \\
\hline N1 & $63(40)$ & 15 & 25 & 23 & \\
\hline $\mathrm{N} 2$ & $31(19)$ & 7 & 10 & 14 & \\
\hline N3 & $18(11)$ & 2 & 5 & 11 & \\
\hline \multicolumn{6}{|l|}{ Differentiation } \\
\hline Superior & $6(4)$ & 3 & 1 & 2 & 0.489 \\
\hline Moderate & $45(28)$ & 10 & 17 & 18 & \\
\hline Inferior & $109(68)$ & 21 & 41 & 47 & \\
\hline \multicolumn{6}{|l|}{ TNM stage } \\
\hline I & $25(16)$ & 15 & 4 & 6 & $<0.001$ \\
\hline II & $67(42)$ & 9 & 26 & 32 & \\
\hline III & $52(32)$ & 7 & 23 & 22 & \\
\hline IV & $16(10)$ & 3 & 6 & 7 & \\
\hline
\end{tabular}

for NF1 protein compared to $58.1 \%$ in gastric cancer tissue samples. Further, low or negative NF1 protein expression was associated with T stage $(P<0.05)$ and tumor node metastasis $(P<0.001)$. Moreover, Kaplan-Meier survival analyses showed that patients with NF1 protein expression had better prognosis than those with low or negative NF1 protein expression $(P<0.001)$. The qRT-PCR data corroborated these findings, and the univariate and multivariate cox regression analysis also demonstrated that NF1 expression was an independent risk factor of survival of GC patients, thereby suggesting that NF1 was a potential prognostic marker for GC.

Many studies have highlighted the role of $N F 1$ in cancers. Yoon et al. reported that NF1 gene product neurofibromin negatively regulated Ras and mammalian 
Table 3: The NF1 mRNA expression in normal and gastric cancer tissues

\begin{tabular}{lcccc}
\hline Tissue type & Total $(\mathbf{n})$ & NF1 positive & \% NF1 positives & $P$ value \\
\hline normal & 160 & 154 & 96.3 & $<0.001$ \\
cancer & 160 & 116 & 72.5 & \\
\hline
\end{tabular}

target of rapamycin (mTOR) signaling and prompted clinical trials to evaluate the ability of Ras and mTOR pathway inhibitors to arrest NF1-associated tumor growth [24]. Verhaak et al. demonstrated strong association

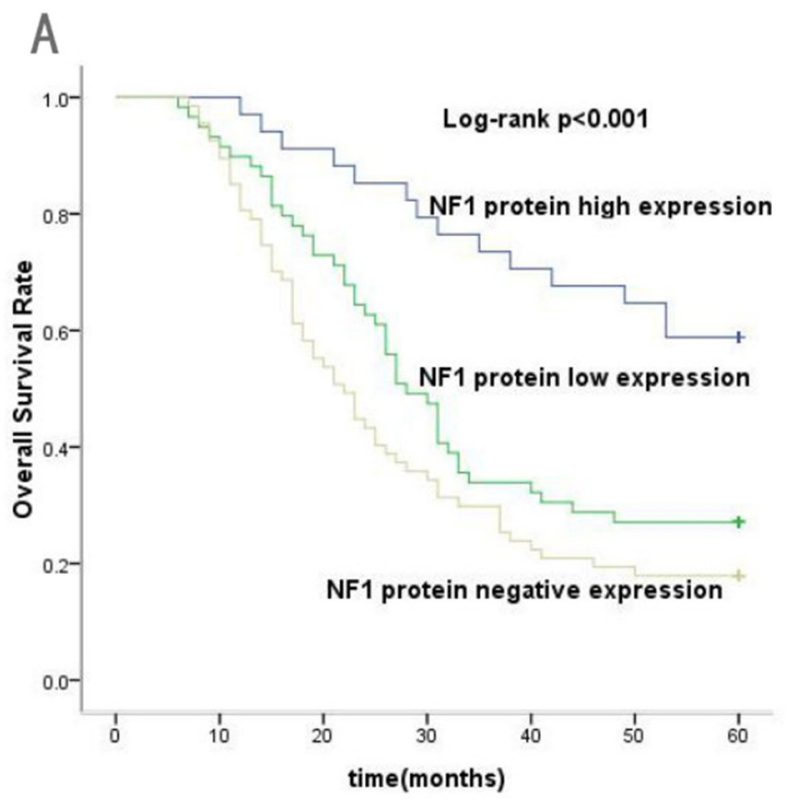

between somatic NF1 mutations and the mesenchymal subtype [23]. Elza et al. demonstrated that low NF1 levels were associated with primary and acquired resistance of lung adenocarcinomas to EGFR TKIs [25]. Another

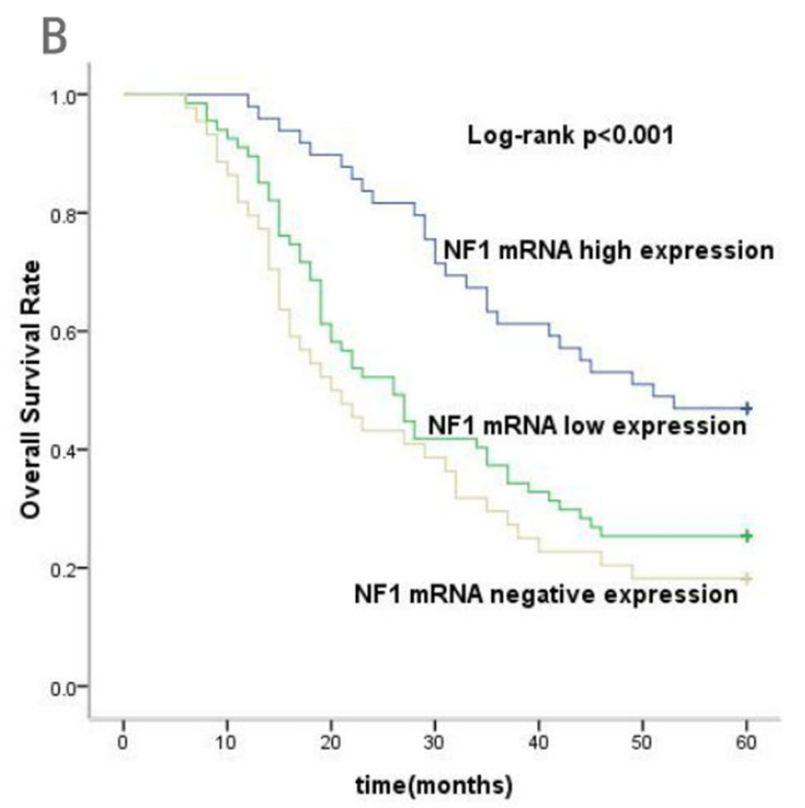

Figure 2: Kaplan-Meier analysis for overall survival (OS) of gastric cancer patients according to the NF1 protein and mRNA expression. (A) Association of high, low or negative NF1 protein expression with $\mathrm{OS}(\mathrm{P}<0.001)$. (B) Association of high, low or negative NF1 mRNA expression with OS $(\mathrm{P}<0.001)$.
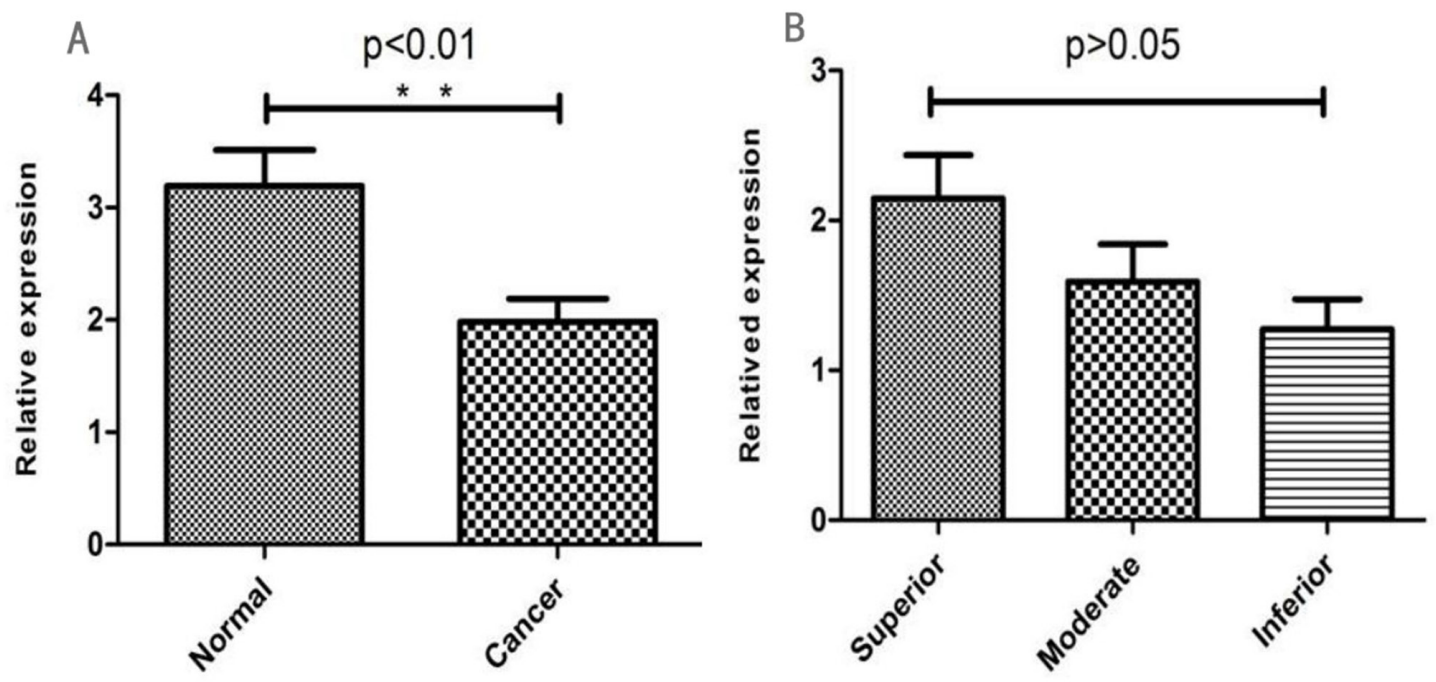

Figure 3: (A) Relative NF1 mRNA levels in normal and GC tissues $(* \mathrm{P}<0.05$; $* * \mathrm{P}<0.01)$. (B) Relative NF1 mRNA levels in different GC differentiation stages $(* \mathrm{P}<0.05 ; * * \mathrm{P}<0.01)$. 
Table 4: Correlation between NF1 mRNA expression and clinicopathological characteristics of GC patients

\begin{tabular}{|c|c|c|c|c|c|}
\hline \multirow[t]{2}{*}{ Characteristics } & \multirow[t]{2}{*}{ n (\%) } & \multicolumn{3}{|c|}{ NF1 mRNA expression (case) } & \multirow[t]{2}{*}{ Pvalue } \\
\hline & & High $(n=42)$ & Low $(n=74)$ & Negative $(n=44)$ & \\
\hline \multicolumn{6}{|l|}{ Age (years) } \\
\hline$<60$ & $64(40)$ & 15 & 31 & 18 & 0.800 \\
\hline$\geq 60$ & $96(60)$ & 27 & 43 & 26 & \\
\hline \multicolumn{6}{|l|}{ Gender } \\
\hline Male & $104(65)$ & 25 & 54 & 25 & 0.141 \\
\hline Female & $56(35)$ & 17 & 20 & 19 & \\
\hline \multicolumn{6}{|l|}{ Tumor size $(\mathrm{cm})$} \\
\hline$<5$ & $91(57)$ & 23 & 41 & 27 & 0.980 \\
\hline$\geq 5$ & $69(43)$ & 19 & 33 & 17 & \\
\hline \multicolumn{6}{|l|}{ Distant metastasis } \\
\hline Yes & $16(10)$ & 2 & 9 & 5 & 0.416 \\
\hline No & 144(90) & 40 & 65 & 39 & \\
\hline \multicolumn{6}{|l|}{ T stage } \\
\hline $\mathrm{T} 1$ & $16(10)$ & 10 & 5 & 1 & 0.011 \\
\hline $\mathrm{T} 2$ & 21(13) & 6 & 11 & 4 & \\
\hline $\mathrm{T} 3$ & $92(58)$ & 22 & 43 & 27 & \\
\hline $\mathrm{T} 4$ & $31(19)$ & 4 & 15 & 12 & \\
\hline \multicolumn{6}{|l|}{$\mathrm{N}$ stage } \\
\hline N0 & $48(30)$ & 16 & 22 & 10 & 0.217 \\
\hline N1 & $63(40)$ & 14 & 30 & 19 & \\
\hline N2 & $31(19)$ & 9 & 15 & 7 & \\
\hline N3 & $18(11)$ & 3 & 7 & 8 & \\
\hline \multicolumn{6}{|l|}{ Differentiation } \\
\hline Superior & $6(4)$ & 2 & 1 & 3 & 0.476 \\
\hline Moderate & $45(28)$ & 14 & 21 & 10 & \\
\hline Inferior & $109(68)$ & 26 & 52 & 31 & \\
\hline \multicolumn{6}{|l|}{ TNM stage } \\
\hline I & $25(16)$ & 15 & 8 & 2 & $<0.001$ \\
\hline II & $67(42)$ & 17 & 27 & 23 & \\
\hline III & $52(32)$ & 8 & 30 & 14 & \\
\hline IV & $16(10)$ & 2 & 9 & 5 & \\
\hline
\end{tabular}

study showed that NF1 was an active regulator of GTPRas accumulation [26]. Also, loss of NFlgene lead to epithelial-mesenchymal transition (EMT), thereby implicating NF1 in tumorigenesis and cancer metastasis [27]. However, NF1 function in GC is unknown and needs to be investigated further.
Although our study demonstrated prognostic value of NF1 in GC patients, there are some limitations in our study. First, the gastric cancer sample size in our study is relatively small that may have introduced inherent bias. Hence, future studies with large-scale samples are necessary to confirm our findings. Second, we did not collect the disease free survival (DFS) data in our study, 
Table 5: Univariate and multivariate cox analyses of survival in patients with GC

\begin{tabular}{lccccc}
\hline Tumor features & B & S.E. & Wald- $\boldsymbol{\chi} \mathbf{2}$ & $\boldsymbol{P}$ & RR (95\%CI) \\
\hline Univariate & & & & & \\
Gender & 0.441 & 0.221 & 3.975 & 0.046 & $1.554(1.008-2.398)$ \\
Age & 0.306 & 0.210 & 2.130 & 0.144 & $1.358(0.900-2.048)$ \\
Tumor size & 0.406 & 0.191 & 4.507 & 0.034 & $1.501(1.032-2.184)$ \\
Differentiation & 0.615 & 0.208 & 8.779 & 0.003 & $1.850(1.231-2.779)$ \\
T stage & 0.506 & 0.127 & 15.878 & $<0.001$ & $1.658(1.293-2.127)$ \\
N stage & 0.282 & 0.097 & 8.510 & 0.006 & $1.326(1.097-1.603)$ \\
Distant metastasis & 0.703 & 0.499 & 1.983 & 0.159 & $2.019(0.759-5.371)$ \\
TNM stage & 0.394 & 0.107 & 13.452 & 0.001 & $1.483(1.201-1.831)$ \\
NF1 expression & 0.531 & 0.128 & 17.115 & $<0.001$ & $1.701(1.322-2.187)$ \\
Multivariate & & & & & \\
T stage & 0.445 & 0.133 & 11.235 & 0.001 & $1.560(1.203-2.023)$ \\
NF1 expression & 0.451 & 0.130 & 11.999 & 0.001 & $1.570(1.216-2.025)$ \\
\hline
\end{tabular}

Table 6: Real time PCR conditions

\begin{tabular}{lccc}
\hline Program & Temperature & Time & $\begin{array}{c}\text { Reaction } \\
\text { times }\end{array}$ \\
\hline $\begin{array}{l}\text { Pre } \\
\text { denaturation }\end{array}$ & $95^{\circ} \mathrm{C}$ & $10 \mathrm{~min}$ & 1 \\
Denaturation & $95^{\circ} \mathrm{C}$ & $10 \mathrm{~s}$ & \\
annealing & $55^{\circ} \mathrm{C}$ & $20 \mathrm{~s}$ & 40 \\
extend & $72^{\circ} \mathrm{C}$ & $15 \mathrm{~s}$ & \\
Insulation & $72^{\circ} \mathrm{C}$ & $3 \mathrm{~min}$ & 1 \\
\hline
\end{tabular}

Table 7: Real time PCR reaction mixture composition

\begin{tabular}{lc}
\hline Reagents & $\begin{array}{c}\text { Usage } \\
\text { amount }\end{array}$ \\
\hline $\begin{array}{l}\text { SYBR } ® \text { Premix Ex Taq II(Tli RNaseH } \\
\text { Plus) }(2 \times)\end{array}$ & $10 \mu \mathrm{l}$ \\
PCR Forward Primer $(10 \mu \mathrm{M})$ & $0.8 \mu \mathrm{l}$ \\
PCR Reverse Primer $(10 \mu \mathrm{M})$ & $0.8 \mu \mathrm{l}$ \\
ROX Reference Dye or Dye II (50×) & $0.4 \mu \mathrm{l}$ \\
RT reaction solution (cDNA solution) & $2 \mu \mathrm{l}$ \\
dH2O (Sterilized distilled water) & $6 \mu \mathrm{l}$ \\
Total & $20 \mu l^{* 4}$ \\
\hline
\end{tabular}

which could be influenced by the postoperative treatment and follow-up examinations. Third, we investigated NF1 gene expression in GC tissues and its association with patient prognosis. However, we did not investigate the mechanisms downstream of NF1. These mechanisms need to be deciphered in future investigations.

In conclusion, our study demonstrated that low or negative NF1 expression in human GC tissues was associated with higher TNM stage and poor five-year overall survival compared to those with high NF1 levels. These data indicated that NF1 was a potential prognostic indicator for the survival of GC patients.

\section{MATERIALS AND METHODS}

\section{Patients and samples}

The present study included primary gastric cancer specimens from 160 patients (104 males and 56 females), who underwent surgery at the Affiliated Hospital of Shandong Academy of Medical Sciences (Shandong, P.R. China) between August 2008 and June 2011. All patients in the present study were confirmed by pathological examination after surgery. The patients did not receive chemotherapy or radiotherapy before surgery. The clinical and pathological data of all patients was obtained by reviewing medical records and pathology reports. These included gender, age, tumor size, tumor differentiation, $\mathrm{T}$ stage, lymph node metastasis, distant metastasis, and tumor-node-metastasis (TNM) stage. Clinicopathological classification and staging was determined according to the criteria recommended by the American Joint Committee on Cancer (AJCC) [28]. The age of the participating patients ranged from 34 to 79 yrs (mean: 54 yrs). Normal tissue was also obtained from all patients and was at least $5 \mathrm{~cm}$ away from the cancer tumors. Further, we obtained survival data from telephone or outpatient follow-ups. The last follow-up 
data was in May 2016. The median follow-up time was 45 months (range: 1-60 months). This study was reviewed and approved by the Ethics Committee of The Affiliated Hospital of Shandong Academy of Medical Sciences. We obtained written informed consent from all participants.

\section{Immunohistochemical staining}

The normal and cancer tissue samples from 160 patients were paraffin embedded and cut into $4 \mu \mathrm{m}$ thick slices for immunohistochemical staining. Immunohistochemical staining was performed using the streptavidin-peroxidase two-stage method. Briefly, the tissue sections were dewaxed, hydrated and subjected to antigen retrieval with EDTA. Next, the samples were incubated with the rabbit anti-NF1 antibody (1:200; CUSABIO BIOTECH CO. Ltd) at $4^{\circ} \mathrm{C}$ overnight. This was followed by incubation with horseradish peroxidase-conjugated anti IgG antibody (1:1000; Santa Cruz, USA) for $45 \mathrm{~min}$ and three washes with PBS for 5 min each. Then, the samples were developed with diaminobenzidine solution for $3 \mathrm{~min}$, washed briefly in running water, counter-stained with hematoxylin, dehydrated through a graded series of alcohol to xylene and sealed piece with a neutral gum. Negative control tissues were stained similarly except that the primary antibody was replaced with PBS.

\section{RNA extraction and real-time quantitative PCR (qRT-PCR)}

Total RNA was extracted from cancer and noncancerous tissues using Trizol (Invitrogen, USA) according to the instructions of the Reverse Transcription System kit (Vazyme Biotech, China). Reverse transcription was performed according to kit instructions followed by quantitative PCR using the Roche 480 II Real-Time PCR machine, and the real time PCR conditions and reaction mixture composition were showed in Tables 6 and 7. All the gene expression levels were analyzed and calculated by using the 2- $\Delta \Delta \mathrm{Ct}$ method [29]. NF1 and $\beta$-Actin primers were purchased from Sangon Biotech Company. The primer sequences for NF1 were: forward, 5'-ACA CATGCAAAATGGGAACA-3' and reverse, 5'-TGGGA CATTCGCCTCTTAAC-3'. The primer sequences for $\beta$-Actin were: forward, 5'-AGCGAGCATCCCCCAA AGTT-3' and reverse, 5'-GGGCACGAAGGCTCAT CATT-3'.

\section{Evaluation of NF1 immunohistochemical staining}

Immunohistochemical stained tissue sections were observed and photographed with a light microscope (Carl Zeiss, Germany). NF1 was detected mainly in the cytoplasm of the normal and tumor cells. The NF1 immunohistochemical stained tissue sections were reviewed and assessed independently by three pathologists in a blinded manner and a consensus was reached for each score. Scoring was based on the percentage of stained tumor cells $(1=<10 \% ; 2=11 \%-50 \% ; 3=>51 \%)$ in a given tumor sample and the intensity of cytoplasmic staining that was graded as negative (score 0 ), weak (score 1), moderate (score 2), or strong (score 3). The final NF1 staining scores were calculated as percentage $\mathrm{x}$ staining intensity. Hence, final scores were, score $0=$ value 0 ; score $1=$ value $1-3$; score $2=$ value $4-6$; score $3=$ value $7-9$. Then, the tissue sections were divided into two groups, low NF1 (score 0 or 1 ) and high NF1 (score 2 or 3 ) groups.

\section{Statistical analysis}

All data were statistically analyzed by SPSS version 17.0 software (SPSS Inc, Chicago, IL, USA). The Pearson's Chi-squared $\left(\chi^{2}\right)$ test was used to evaluate the difference between levels of NF1 staining in specimens and clinicopathological characteristics. The KaplanMeier survival analysis method was used to assess the association between NF1 expression and overall survival. The log-rank test was used to evaluate the differences between survival curve of patients with high or low NF1 expression. To determine prognostic factors, multivariate regression analysis was performed using the Cox proportional hazards model for variables with $P<0.05$ in the univariate Cox analyses. All $P$ values were two-sided and a $P$ value less than 0.05 were considered statistically significant.

\section{ACKNOWLEDGMENTS}

We thank oncotarget's "English Edit OT" Language Editing service for editing the manuscript.

\section{CONFLICTS OF INTEREST}

The authors declare no conflicts of interest.

\section{GRANT SUPPORT}

The study was supported by funding from the National Natural Science Foundation of China (81403150, 81403106, 81274174)

\section{REFERENCES}

1. Fock KM. Review article: the epidemiology and prevention of gastric cancer. Aliment Pharmacol Ther. 2014; 40:250-260.

2. Feng F, Sun L, Liu Z, Liu S, Zheng G, Xu G, Guo M, Lian $X$, Fan D, Zhang H. Prognostic values of normal preoperative serum cancer markers for gastric cancer. Oncotarget. 2016; 7:58459-58469. https://doi.org/10.18632/oncotarget.11248. 
3. Ajani JA, Bentrem DJ, Besh S, D'Amico TA, Das P, Denlinger C, Fakih MG, Fuchs CS, Gerdes H, Glasgow RE, Hayman JA, Hofstetter WL, Ilson DH, et al. Gastric cancer version 2.2013: featured updates to the NCCN Guidelines. J Natl Compr Canc Netw. 2013; 11:531-546.

4. Wu ZJ, Liu B, Zheng XM, Hou HJ, Li Y. Role of the PEBP4 protein in the development and metastasis of gastric cancer. Oncotarget. 2017; 11:18177-18184. https://doi. org/10.18632/oncotarget.15255.

5. Jeon YW, Kim RM, Lim ST, Choi HJ, Suh YJ. Early-onset breast cancer in a family with neurofibromatosis type 1 associated with a germline mutation in BRCA1. J Breast Cancer. 2015; 18:97-100.

6. Zhu L, Zhang Y, Tong H, Shao M, Gu Y, Du X, Wang P, Shi L, Zhang L, Bi M, Wang X, Zhang G. Clinical and molecular characterization of NF1 patients: singlecenter experience of 32 patients from China. Medicine (Baltimore). 2016; 95:e3043.

7. Van Der Gucht A, Zehou O, Djelbani-Ahmed S, ValeyrieAllanore L, Ortonne N, Brugières P, Wolkenstein P, Luciani A, Rahmouni A, Sbidian E, Itti E. Metabolic tumour burden measured by 18 F-FDG PET/CT predicts malignant transformation in patients with neurofibromatosis type-1. PLoS One. 2016; 11:e0151809.

8. Ratner N, Miller SJ. A RASopathy gene commonly mutated in cancer: the neurofibromatosis type 1 tumour suppressor. Nat Rev Cancer. 2015; 15:290-301.

9. Xu GF, O'Connell P, Viskochil D, Cawthon R, Robertson M, Culver M, Dunn D, Stevens J, Gesteland R, White R. The neurofibromatosis type 1 gene encodes a protein related to GAP. Cell. 1990; 62:599-608.

10. Bollag G, McCormick F. Differential regulation of rasGAP and neurofibromatosis gene product activities. Nature. 1991; 351:576-579.

11. Mochizuki H, Nishi T, Bruner JM, Lee PS, Levin VA, Saya H. Alternative splicing of neurofibromatosis type 1 gene transcript in malignant brain tumours: PCR analysis of frozen-section mRNA. Mol Carcinogen. 1992; 6:83-87.

12. Wallace MD, Pfefferle AD, Shen L, McNairn AJ, Cerami EG, Fallon BL, Rinaldi VD, Southard TL, Perou CM, Schimenti JC. Comparative oncogenomics implicates the neurofibromin 1 gene (NF1) as a breast cancer driver. Genetics. 2012; 192:385-396.

13. Cacev T, Radosević S, Spaventi R, Pavelić K, Kapitanović S. NF1 gene loss of heterozygosity and expression analysis in sporadic colon cancer. Gut. 2005; 54:1129-1135.

14. Furukawa K, Yanai N, Fujita M, Harada Y. Novel mutations of neurofibromatosis type 1 gene in small cell lung cancers. Surg Today. 2003; 33:323-327.

15. Gutmann DH, Geist RT, Rose K, Wallin G, Moley JF. Loss of neurofibromatosis type I (NF1) gene expression in pheochromocytomas from patients without NF1. Genes Chromosomes Cancer. 1995; 13:104-109.
16. Laudański $P$, Kowalczuk O, Klasa-Mazurkiewicz D, Milczek T, Rysak-Luberowicz D, Garbowicz M, Baranowski W, Charkiewicz R, Szamatowicz J, Chyczewski L. Selective gene expression profiling of mTOR- associated tumor suppressor and oncogenes in ovarian cancer. Folia Histochem Cytobiol. 2011; 49:317-324.

17. Vizcaíno MA, Shah S, Eberhart CG, Rodriguez FJ. Clinicopathologic implications of NF1 gene alterations in diffuse gliomas. Hum Pathol. 2015; 46:1323-1330.

18. Li Y, O'Connell P, Breidenbach HH, Cawthon R, Stevens J, Xu G, Neil S, Robertson M, White R, Viskochil D. Genomic organization of the neurofibromatosis 1 gene (NF1). Genomics. 1995; 25:9-18.

19. Banerjee S, Byrd JN, Gianino SM, Harpstrite SE, Rodriguez FJ, Tuskan RG, Reilly KM, Piwnica-Worms DR, Gutmann DH. The neurofibromatosis type 1 tumor suppressor controls cell growth by regulating signaltransducer and activator of transcription-3 activity in vitro and in vivo. Cancer Res. 2010; 70:1356-1366.

20. Ding L, Wilson RK. Somatic mutations affect key pathways in lung adenocarcinoma. Nature. 2008; 455:1069-1075.

21. Boudry-Labis E, Roche-Lestienne C, Nibourel O, Boissel N, Terre C, Perot C, Eclache V, Gachard N, Tigaud I, Plessis G, Cuccuini W, Geffroy S, Villenet C, et al. Neurofibromatosis-1 gene deletions and mutations in de novo adult acute myeloid leukemia. Am J Hematol. 2013; 88:306-311.

22. Larizza L, Gervasini C, Natacci F, Riva P. Developmental abnormalities and cancer predisposition in neurofibromatosis type 1. Curr Mol Med. 2009; 9:634-653.

23. Iyengar TD, Ng S, Lau CC, Welch WR, Bell DA, Berkowitz RS, Mok SC. Differential expression of NF1 type I and type II isoforms in sporadic borderline and invasive epithelial ovarian tumors. Oncogene. 1999; 18:257-262.

24. Yap YS, McPherson JR, Ong CK, Rozen SG, Teh BT, Lee AS, Callen DF. The NF1 gene revisited - from bench to bedside. Oncotarget. 2014; 15:5873-5892. https://doi. org/10.18632/oncotarget.2194.

25. de Bruin EC, Cowell C, Warne PH, Jiang M, Saunders RE, Melnick MA, Gettinger S, Walther Z, Wurtz A, Heynen GJ, Heideman DA, Gómez-Román J, García-Castaño A, et al. Reduced NF1 expression confers resistance to EGFR inhibition in lung cancer. Cancer Discov. 2014; 4:606-619.

26. Bajaj A, Li QF, Zheng Q, Pumiglia K. Loss of NF1 expression in human endothelial cells promotes autonomous proliferation and altered vascular morphogenesis. PLoS One. 2012; 7:e49222.

27. Arima Y, Hayashi H, Kamata K, Goto TM, Sasaki M, Kuramochi A, Saya H. Decreased expression of neurofibromin contributes to epithelial-mesenchymal transition in neurofibromatosis type 1. Exp Dermatol. 2010; 19:e136-141. 
28. Carey LA, Metzger R, Dees EC, Collichio F, Sartor CI, Ollila DW, Klauber-DeMore N, Halle J, Sawyer L, Moore DT, Graham ML. American Joint Committee on Cancer tumor-node-metastasis stage after neoadjuvant chemotherapy and breast cancer outcome. J Natl Cancer Inst. 2005; 97:1137-1142.
29. Yin K, Liu M, Zhang M, Wang F, Fen M, Liu Z, Yuan Y, Gao S, Yang L, Zhang W, Zhang J, Guo B, Xu J, et al. miR208a-3p suppresses cell apoptosis by targeting PDCD4 in gastric cancer. Oncotarget. 2016; 7:67321-67332. https:// doi.org/10.18632/oncotarget.12006. 